\title{
Functional characterisation of a recombinant xylanase from Pichia pastoris and effect of the enzyme on nutrient digestibility in weaned pigs
}

\author{
Jun $\mathrm{He}^{1,2}$, Jia Yin ${ }^{1,2}$, Li Wang ${ }^{1,2}$, Bing Yu ${ }^{1,2}$ and Daiwen Chen ${ }^{1,2 *}$ \\ ${ }^{1}$ Institute of Animal Nutrition, Sichuan Agricultural University, Yaan, Sichuan 625014, China \\ ${ }^{2}$ Key Laboratory of Animal Disease-Resistance Nutrition, Ministry of Education, China \\ (Received 10 June 2009 - Revised 6 November 2009 - Accepted 9 November 2009 - First published online 12 January 2010)
}

The xyn2 gene of a filamentous mesophilic fungus, Trichoderma reesei, coding xylanase 2 (Xyn2) was previously expressed in Pichia pastoris. In the present study, the recombinant Xyn2 was prepared from a 15 litre fermenter, and subsequently characterised. It has been confirmed to have a molecular mass of $21 \mathrm{kDa}$, an optimal $\mathrm{pH}$ of 6.0 and an optimal temperature of $60^{\circ} \mathrm{C}$. When tested using oat-spelt xylan, it showed a $K_{m}$ and catalytic rate constant $\left(k_{\text {cat }}\right)$ of $1.1 \mathrm{mg} / \mathrm{ml}$ and $512.4 / \mathrm{s}$, respectively. Analysis of the products from oat-spelt xylan degradation confirmed that the enzyme was an endoxylanase with xylotriose and xylobiose as the main degradation products. The unprocessed Xyn 2 was supplemented to a xylan-containing diet to determine its influences on performance and nutrient digestibilities by weaned pigs. Results showed that the average body-weight gain increased $16.9 \%$ when piglets received Xyn2 at a concentration of $500 \mathrm{U} / \mathrm{kg}$ diet. There also was a positive $(0.05<P<0.10)$ effect on the digestibility values of crude protein, ash, Ca and acid-detergent fibre with Xyn 2 supplementation. The potential benefits of Xyn2 in the nutrition of weaned pigs should make it an alternative applicant for industrial xylanase production.

Xylanase: Characterisation: Weaned pigs: Supplementation: Digestibility

Xylan, the major component of hemicellulose, is a heterogeneous polysaccharide with a backbone consisting of a $\beta$-D- $(1 \rightarrow 4)$ linked xylopyranoside backbone substituted with many side chains. Complete breakdown of xylans requires the synergistic action of several enzymes of which endo- $\beta-1,4$-xylanases (EC 3.2.1.8) are the crucial enzymes for depolymerisation ${ }^{(1)}$. In recent years, xylanases have attracted considerable research interest because of their potential benefits in the animal nutrition and feed industry ${ }^{(2,3)}$. The cell walls of cereals contain up to $15 \%$ NSP; exogenous enzymes can hydrolyse these carbohydrates into smaller units that can be utilised by animals.

The fungus Trichoderma reesei is a filamentous mesophilic fungus which has been shown to secrete large amounts of efficient xylan-degrading enzymes ${ }^{(4)}$. The $T$. reesei xylanase 2 (Xyn2) has been in industrial use for many years, since it represents more than $50 \%$ of the total xylanolytic activity of this fungus ${ }^{(5)}$. However, the industrial enzymes are often used in the unpurified form. There are many side activities that can be a problem with the use of these enzymes ${ }^{(4)}$. For instance, the relatively crude xylanase preparation with residual cellulolytic activity requires the careful control of process parameters to avoid damage to fibres. In addition, the residual protease may degrade xylanases of interest over time ${ }^{(6,7)}$. The $T$. reesei Xyn2 produced in a recombinant host has an advantage of showing xylanase activity that is practically free of harmful side activities. Therefore, the recombinant production hosts are preferred ${ }^{(6-8)}$. We have previously expressed the xyn2 gene in Pichia pastoris and achieved a high expression level of $500 \mathrm{U} / \mathrm{ml}$ in a 5 litre fermenter (He Jun, Yu Bing, Zhang Keying and Chen Daiwen, unpublished results). To evaluate its potential benefits for industrial applications, especially in the animal nutrition and feed industry, the enzyme has been studied to understand its physical and biochemical characteristics. Furthermore, a trial with weaned pigs has been carried out to validate the potential benefits under practical conditions.

\section{Materials and methods \\ Micro-organisms and media}

Recombinant $P$. pastoris (PX-1) was previously constructed and conserved in our laboratory. PX-1 was cultivated on either buffered glycerol-complex medium (1\% yeast extract, $2 \%$ peptone, $1.34 \%$ yeast nitrogen base, $1 \%$ glycerol) or buffered methanol-complex medium ( $1 \%$ yeast extract, $2 \%$ peptone, $1.34 \%$ yeast nitrogen base, $1 \%$ methanol), respectively. Zeocin was added to a final concentration of $100 \mu \mathrm{g} / \mathrm{ml}$.

\section{Xylanase 2 production in a 15 litre fermenter}

A large-scale production was performed (six times) in a 15 litre fermenter (Nanjing Runze Bioengineering Equipment

Abbreviations: HD, Xyn2 added at a concentration of $1500 \mathrm{U} / \mathrm{kg}$ diet; LD, Xyn2 added at a concentration of 500 U/kg diet; MD, Xyn2 added at a concentration of $1000 \mathrm{U} / \mathrm{kg}$ diet; PX-1, recombinant Pichia pastoris; Xyn2, xylanase 2.

* Corresponding author: Dr Daiwen Chen, fax +86 835 2885106, email Daiwenc@yahoo.com 
Co. Ltd, Nanjing, China). PX-1 was cultured in 2 litre Erlenmeyer flasks containing $500 \mathrm{ml}$ of buffered glycerolcomplex medium at $30^{\circ} \mathrm{C}$ on a rotary shaker at $200 \mathrm{rpm}$. After $18-20 \mathrm{~h}$ incubation, cell pellets were harvested by centrifugation at $3000 \mathrm{~g}$ for $5 \mathrm{~min}$. For xylanase induction, the cell pellets were re-suspended in 9 litres of buffered methanol-complex medium. The induction was maintained for $5 \mathrm{~d}$ by adding absolute methanol to a final concentration of $1 \%$ every day. Relative percentage of dissolved oxygen was maintained above $30 \%$ via adjusting the agitation rate. Supernatant fraction samples were collected every day and kept at $-80^{\circ} \mathrm{C}$ before analysis. At the end of fermentation, all culture supernatant fraction was collected by centrifugation and subsequently used as the enzyme source for the animal trial.

\section{SDS-PAGE and enzyme activity assay}

SDS-PAGE on $15 \%$ polyacrylamide was performed by the method of Laemmli ${ }^{(9)}$. The protein fractions (induction supernatant fraction) were boiled for $3 \mathrm{~min}$ and applied to the gel. Proteins were visualised by Coomassie brilliant blue R 250 staining. The protein concentration was determined by the Bradford assay using bovine serum albumin as a standard $^{(10)}$. Xylanase activity was assayed by the method described by Bailey et al. ${ }^{(11)}$, with $1 \%$ oat-spelt xylan (Sigma, St Louis, MO, USA) as the substrate at $50^{\circ} \mathrm{C}$ for $10 \mathrm{~min}$. Appropriate dilutions of the recombinant protein (culture supernatant fraction) in $50 \mathrm{~mm}$-sodium citrate buffer ( $\mathrm{pH}$ 5.0) were used as the enzyme source. The amount of released sugar was determined by the dinitrosalicylic acid method described by Miller et al. ${ }^{(12)}$. One unit of xylanase activity was defined as the quantity of enzyme that liberated reducing sugar at the rate of $1 \mu \mathrm{mol} / \mathrm{s}$. The temperature optimum was measured by performing the xylanase activity assay at temperatures ranging from 20 to $90^{\circ} \mathrm{C}$. Thermostability was tested by heating the enzyme samples for different times at various temperatures, and the activity was assayed at $50^{\circ} \mathrm{C}$ for $10 \mathrm{~min}$. Assays at different $\mathrm{pH}$ values were performed at the optimal temperature over a $\mathrm{pH}$ range of 3.0 to 8.0 . The buffers used were $50 \mathrm{mM}$-citrate $(\mathrm{pH} 3.0)$, $50 \mathrm{~mm}$-citrate phosphate ( $\mathrm{pH} 4.0$ to $7 \cdot 0)$ and $50 \mathrm{mM}$-phosphate (pH 8.0), respectively.

\section{Analysis of substrate specificity and hydrolysis products}

The substrates (birchwood xylan, oat-spelt xylan, beechwood xylan, gellan gum and carboxymethyl cellulose) were purchased from Sigma Chemical Co. (St Louis, MO, USA). Avicel (cellulose microcrystalline) was purchased from Merck (Darmstadt, Germany). The determining of substrate specificity was carried out in $50 \mathrm{~mm}$-citrate phosphate $(\mathrm{pH}$ 5.0 ) containing $2.0 \mathrm{mg} / \mathrm{ml}$ of each substrate at $50^{\circ} \mathrm{C}$ for $10 \mathrm{~min}$. For each assay, six different substrate concentrations were prepared in $50 \mathrm{mM}$-citrate phosphate $(\mathrm{pH} \mathrm{5.0)}$, and incubated with the enzyme at $50^{\circ} \mathrm{C}$ for $5 \mathrm{~min}$. The $K_{m}$ and catalytic rate constant $\left(k_{c a t}\right)$ values were calculated from the kinetics data as described by Jiang et al. ${ }^{(8)}$.

Oat-spelt xylan $(40 \mathrm{mg})$ was incubated with $100 \mathrm{U}$ of the enzyme in $2 \mathrm{ml} 50 \mathrm{~mm}$-citrate phosphate $(\mathrm{pH} 5.0)$ and the reaction was performed at $50^{\circ} \mathrm{C}$ for $12 \mathrm{~h}$. The hydrolysis products were analysed by TLC using silica gel plates $60 \mathrm{~F}$ 254 (E. Merck, Darmstadt, Germany). Aliquots $(100 \mu \mathrm{l})$ of the samples were collected at 5,10 and $30 \mathrm{~min}$, and at 1,2, 4,8 and $12 \mathrm{~h}$ of the incubation period and $1 \mu \mathrm{l}$ of the sample was spotted on the TLC plates. The plates were subsequently developed with two runs of acetonitrile-water $(85: 15, \mathrm{v} / \mathrm{v})$ followed by heating for a few minutes at $130^{\circ} \mathrm{C}$ in an oven after spraying the plates with a methanol-sulfuric acid mixture $(95: 5, \mathrm{v} / \mathrm{v})^{(8)}$. A xylo-oligosaccharide mixture (Suntory Ltd, Osaka, Japan) consisting of xylose, xylobiose and xylotriose was used as the standard.

\section{Animals and housing}

The experimental protocols used in the present study were approved by Sichuan Agricultural University Institutional Animal Care and Use Committee. Twenty-four weaned pigs (Duroc $\times$ Landrace $\times$ Yorkshire) with an average initial body weight of $10.2 \pm 0.35 \mathrm{~kg}$ were selected and randomly allotted to four dietary treatments $(n \quad 6)$ with equal numbers of males and females in each group. Treatments consisted of: (1) control without Xyn2 supplementation; (2) Xyn2 added at a concentration of $500 \mathrm{U} / \mathrm{kg}$ diet (LD); (3) Xyn2 added at a concentration of $1000 \mathrm{U} / \mathrm{kg}$ diet (MD); (4) Xyn2 added at a concentration of $1500 \mathrm{U} / \mathrm{kg}$ diet (HD).

Pigs were housed individually in metabolism cages $(0.7 \times 1.5 \mathrm{~m})$ with woven wire flooring in an environmentally controlled room $\left(22-24^{\circ} \mathrm{C}\right)$ and were given ad libitum access to water through a water nipple. Pigs were hand-fed four times per d (08.00, 12.00, 16.00 and 20.00 hours) in bowl feeders to make sure fresh feed was available, and allowed a $5 \mathrm{~d}$ adjustment to the experimental diets. The diet adjustment period was followed by a collection period, which include a $4 \mathrm{~d}$ collection of faeces to determine the apparent nutrient digestibility. Pig weights and feed consumption were determined daily throughout the duration of the trial.

\section{Experimental diets}

To prepare a diet containing sufficient amounts of the target substrate (xylan), both wheat and wheat bran were utilised. The diet was formulated on the basis of nutrient requirements for $10-20 \mathrm{~kg}$ pigs (National Research Council ${ }^{(13)}$ ). Dietary amino acids were supplied by maize, wheat, soyabean meal, rapeseed meal, fish meal, and vitamin and minerals were supplied by vitamin and mineral supplements (Table 1). Synthetic DL-methionine was added to the diets to meet minimal methionine-cystine concentrations. Each ingredient source was analysed for protein and amino acid content. The analysed amino acid contents of the ingredients were used to formulate the experimental diets. The unprocessed enzyme (obtained from fermentation) was added to the diet by using a portion of the basal diet $(5.0 \mathrm{~kg} / 100 \mathrm{~kg}$ of entire diet) as the carrier.

\section{Sample collection and analysis}

Faeces were collected and weighed every $24 \mathrm{~h}$, with $5 \%$ samples being saved and blended for each pig within the collection period. Then the total quantity of faeces collected was pooled and freeze-dried to a constant weight. The dried 
Table 1. Composition of experimental diets (as-fed basis)

\begin{tabular}{|c|c|}
\hline & $\%$ of diet \\
\hline \multicolumn{2}{|l|}{ Ingredients } \\
\hline Maize & 52.9 \\
\hline Wheat & $15 \cdot 0$ \\
\hline Wheat bran & $5 \cdot 0$ \\
\hline Soyabean meal & 11.4 \\
\hline Extruded soyabean & 4.9 \\
\hline Rapeseed meal & $5 \cdot 2$ \\
\hline Fish meal & $2 \cdot 2$ \\
\hline Rapeseed oil & $0 \cdot 18$ \\
\hline L-Lysine & 0.31 \\
\hline DL-Methionine & 0.02 \\
\hline Threonine & 0.07 \\
\hline $\mathrm{CaCO}_{3}$ & 0.88 \\
\hline $\mathrm{CaHPO}_{4}$ & 1.09 \\
\hline Salt & 0.30 \\
\hline Vitamin premix ${ }^{*}$ & 0.15 \\
\hline Trace mineral premix $\dagger$ & 0.30 \\
\hline Choline chloride & $0 \cdot 10$ \\
\hline $\mathrm{NaHCO}_{3}$ & 0.24 \\
\hline Total & 100 \\
\hline \multicolumn{2}{|l|}{ Analysed composition } \\
\hline Dietary energy $(\mathrm{MJ} / \mathrm{kg})$ & $13 \cdot 97$ \\
\hline Crude protein (\%) & $18 \cdot 01$ \\
\hline Ca $(\%)$ & 0.83 \\
\hline Available P (\%) & 0.41 \\
\hline L-Lysine $(\%)$ & 1.04 \\
\hline Methionine + cysteine (\%) & 0.59 \\
\hline Threonine (\%) & 0.57 \\
\hline Tryptophan (\%) & $0 \cdot 17$ \\
\hline Isoleucine (\%) & 0.53 \\
\hline Xylan (\%) & $5 \cdot 76$ \\
\hline
\end{tabular}

*To provide (per kg): $5.7 \mu \mathrm{g}$ vitamin A; $24.25 \mu \mathrm{g}$ vitamin E; $9.65 \mu \mathrm{g}$ vitamin $\mathrm{D} ; 1.1 \mathrm{mg}$ vitamin $\mathrm{K}$ (menadione dimethylpyrimidinol bisulfate); $5 \mathrm{mg}$ vitamin $\mathrm{B}_{1} ; 15 \mathrm{mg}$ riboflavin; $25 \mathrm{mg}$ niacin; $30 \mathrm{mg}$ d-pantothenic acid; $0.05 \mathrm{mg}$ vitamin $\mathrm{B}_{12}$.

†To provide the following (mg/kg entire diet): $\mathrm{Fe}$ as $\mathrm{FeSO} 4 \cdot 7 \mathrm{H}_{2} \mathrm{O}$, $100 \mathrm{mg}$; $\mathrm{Mn}$ as $\mathrm{MnSO} 4.7 \mathrm{H}_{2} \mathrm{O}, 40 \mathrm{mg} ; \mathrm{Zn}$ as $\mathrm{ZnO}, 80 \mathrm{mg}$; $\mathrm{Cu}$ as CuSO4. $5 \mathrm{H}_{2} \mathrm{O}, 10 \mathrm{mg}$; Se as $\mathrm{NaSeO}_{3}, 0.3 \mathrm{mg}$; iodine as $\mathrm{KI}, 0.3 \mathrm{mg}$.

faecal matter was ground and stored at $4{ }^{\circ} \mathrm{C}$ until it was analysed for nutrients.

Quantitative composition was determined on each of the samples using the following analytical methods: DM content according to AOAC method $964 \cdot 22$; crude protein according to method 955.04; ash according to method 923.03; Ca according to method 927.02; $\mathrm{P}$ according to method $965 \cdot 05^{(14)}$. The acid-detergent fibre content was determined following the procedures of Van Soest et al. ${ }^{(15)}$. Gross energy was determined using an adiabatic oxygen bomb calorimeter (Parr Instrument Co., Moline, IL, USA).

\section{Calculation and statistical analysis}

The experimental model used was a completely randomised design with four treatments of added enzyme. Data from the animal trial were analysed with an ANOVA procedure of SPSS 13.0 (SPSS Inc., Chicago, IL, USA) followed by Duncan's test for multi-group comparisons. To determine whether there was a significant linear response to the enzyme, the orthogonal polynomial contrasts were carried out using the general linear model (GLM) procedure. Data were expressed as mean values with their standard errors. Differences with $P<0.05$ were considered to be significant.

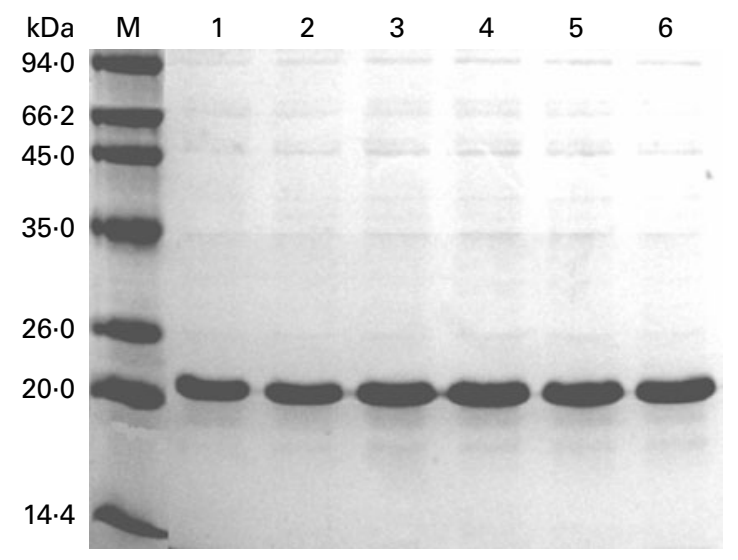

Fig. 1. SDS-PAGE analysis for products in the culture supernatant fraction. $M$, protein marker; 1-6, culture supernatant fraction after $60,66,72,78,84$ and $90 \mathrm{~h}$ fermentation.

\section{Results}

Xylanase 2 production in a 15 litre fermenter

The recombinant $P$. pastoris $\mathrm{PX}-1$ was cultured in a 15 litre fermenter. To determine the highest xylanase yield, the experiment was repeated three times. The size of recombinant xylanase (Xyn2) determined by SDS-PAGE was $21 \mathrm{kDa}$, similar to that of the native xylanase secreted by $T$. reesei (Fig. 1). Xyn2 was the major protein (over $90 \%$ of total protein as detected by densitometry) secreted by PX-1 into the culture medium. Therefore, the procedure for protein purification was not necessary. The highest xylanase activity $(560 \mathrm{U} / \mathrm{ml})$ in the culture supernatant fraction was recorded after $78 \mathrm{~h}$ induction (Fig. 2). However, the highest cell wet weight $(78 \mathrm{~g} / \mathrm{l})$ was obtained at $96 \mathrm{~h}$. Both xylanase activity and cell wet weight decreased slightly in the late induction period (after $96 \mathrm{~h}$ ).

\section{Effect of $p H$ and temperature on $\beta$-xylanase activity}

The recombinant $\beta$-xylanase activity peaked between $\mathrm{pH} 4.5$ and $7 \cdot 5$, with the highest activity measured at $\mathrm{pH} 6.0$ in $50 \mathrm{~mm}$-citrate buffer (Fig. 3(A)). The optimal temperature

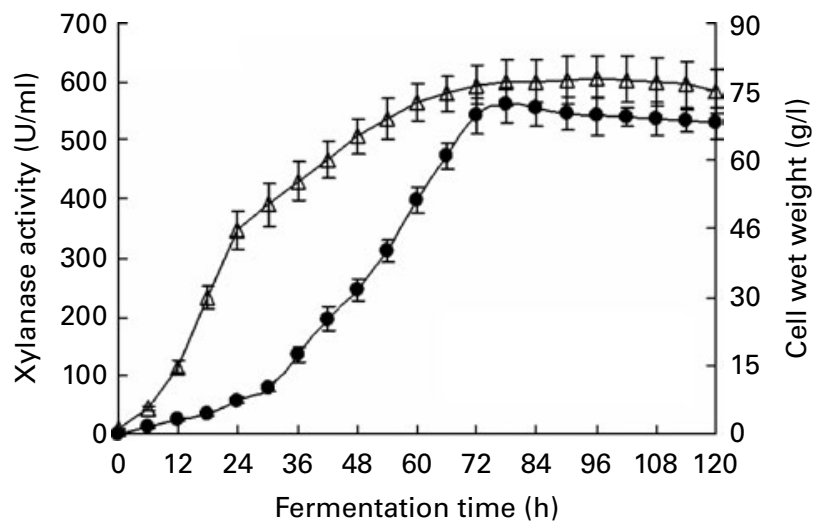

Fig. 2. Enzyme production of Pichia pastoris (PX-1) and cell wet weight after induction at different times. (-๑-), Xylanase activity; $(-\Delta-)$, cell wet weight. Values are means, with standard errors represented by vertical bars. 
(A)
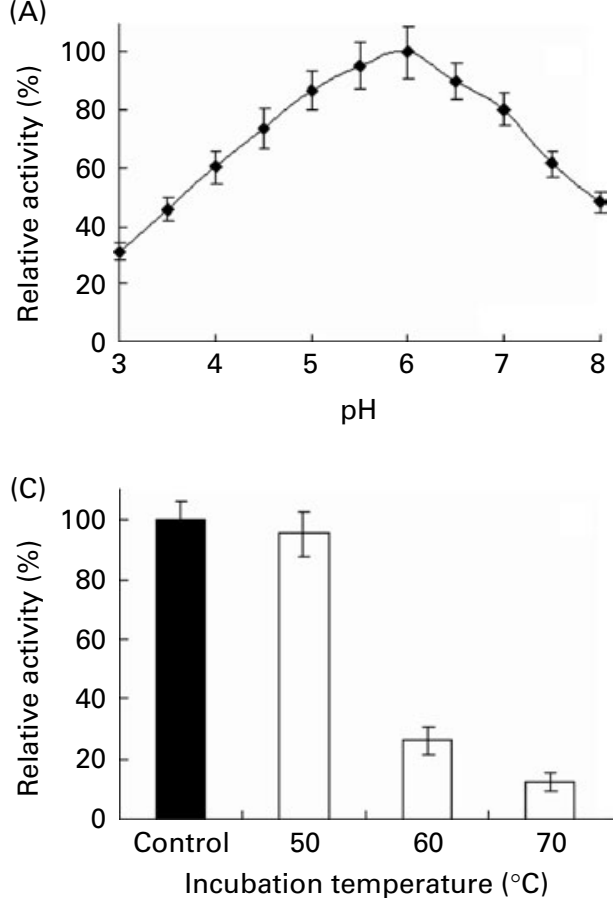

(B)
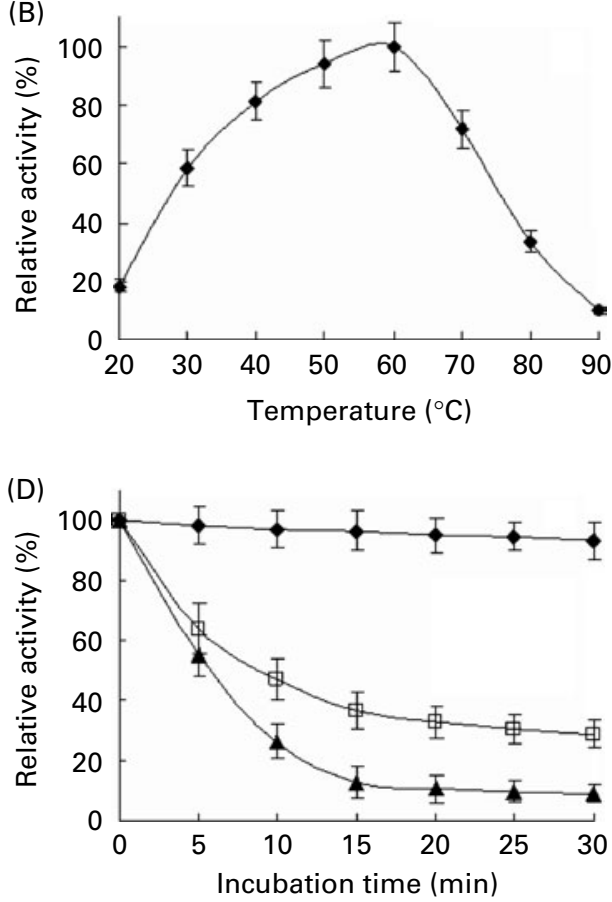

Fig. 3. Characterisation of the recombinant xylanase 2 (Xyn2). (A) Effect of pH on the activity of Xyn2. (B) Effect of temperature on the activity of Xyn2. (C) Determination of temperature stability after preincubating the enzyme in the absence of the substrate for 30 min at 50,60 and $70^{\circ} \mathrm{C}$. (D) Determination of thermostability at different temperatures $\left(50^{\circ} \mathrm{C}(--), 60^{\circ} \mathrm{C}(-\square-)\right.$ and $\left.70^{\circ} \mathrm{C}(-\boldsymbol{\Delta}-)\right)$ by preincubating the enzyme at these temperatures in the absence of substrate for 5,10 , $15,20,25$ and $30 \mathrm{~min}$ before measuring its activity. The xylanase activity before the preincubations at different temperatures was taken as $100 \%$. Values are means, with standard errors represented by vertical bars.

for this enzyme was at $60^{\circ} \mathrm{C}$ (Fig. 3(B)). Although the highest activity was measured at $60^{\circ} \mathrm{C}$, the enzyme was not stable at this temperature (only $30 \%$ activity retained after $30 \mathrm{~min}$ incubation at $60^{\circ} \mathrm{C}$ ). However, the enzyme was stable at $50^{\circ} \mathrm{C}$, and the total activity remained more than $94 \%$ after $30 \mathrm{~min}$ incubating at this temperature (Fig. 3(C) and (D)).

\section{Analysis of substrate specificity and hydrolysis products}

The hydrolytic activity of the recombinant enzyme on various substrates was determined (Table 2). The highest activity $(100 \%)$ was observed with the oat-spelt xylan followed by the birchwood xylan $(91 \%)$. The enzyme exhibited relatively low activities towards cellulosic substrates, such as gellan gum $(12 \%)$, Avicel $(1.7 \%)$ and carboxymethyl cellulose $(1.5 \%)$. The Michaelis-Menten constants were determined for the substrates. The $K_{m}$ and catalytic rate constant $\left(k_{c a t}\right)$ were $1.8 \mathrm{mg} / \mathrm{ml}$ and $435.7 / \mathrm{s}$ for birchwood xylan, and $1.1 \mathrm{mg} / \mathrm{ml}$ and $512 \cdot 4 / \mathrm{s}$ for oat-spelt xylan, respectively. The predominant endproducts of hydrolysis of oat-spelt xylan were xylobiose and xylotriose (Fig. 4). The results confirmed that the recombinant Xyn2 was an endoxylanase.

\section{Effect of xylanase 2 on performance of weaned pigs}

As shown in Fig. 5, there was a positive effect of enzyme treatment $(500 \mathrm{U} / \mathrm{kg})$ on average daily body-weight gain

Table 2. Substrate specificity and kinetic constants for the recombinant xylanase (Mean values with their standard errors of six replications)

\begin{tabular}{|c|c|c|c|c|c|c|c|}
\hline \multirow[b]{2}{*}{ Substrate } & \multicolumn{2}{|c|}{$\begin{array}{c}\text { Enzyme } \\
\text { activity (U/ml) }\end{array}$} & \multirow[b]{2}{*}{ Relative activity $(\%)^{\star}$} & \multicolumn{2}{|c|}{$K_{m}(\mathrm{mg} / \mathrm{ml})$} & \multicolumn{2}{|c|}{$k_{\text {cat }}($ per s) } \\
\hline & Mean & SEM & & Mean & SEM & Mean & SEM \\
\hline Oat-spelt xylan & 560 & $29 \cdot 2$ & 100 & $1 \cdot 1$ & 0.09 & $512 \cdot 4$ & $25 \cdot 2$ \\
\hline Birchwood xylan & 508 & $23 \cdot 7$ & 91 & $1 \cdot 8$ & 0.12 & $435 \cdot 7$ & $21 \cdot 5$ \\
\hline Beechwood xylan & 485 & $19 \cdot 8$ & 82 & $2 \cdot 1$ & 0.15 & $339 \cdot 6$ & $16 \cdot 7$ \\
\hline Gellan gum & 67 & $5 \cdot 1$ & 12 & \multicolumn{2}{|c|}{ NAt } & \multicolumn{2}{|c|}{ NAt } \\
\hline Avicel & $9 \cdot 5$ & 0.8 & $1 \cdot 7$ & \multicolumn{2}{|c|}{ NA† } & \multicolumn{2}{|c|}{ NAt } \\
\hline Carboxymethyl cellulose & $8 \cdot 4$ & 0.6 & 1.5 & \multicolumn{2}{|c|}{ NAt } & \multicolumn{2}{|c|}{ NAt } \\
\hline
\end{tabular}

$k_{\text {cat }}$, Catalytic rate constant; NA, not available.

* The activity for oat-spelt xylan was defined as $100 \%$.

†Difficult to measure, so not presented. 


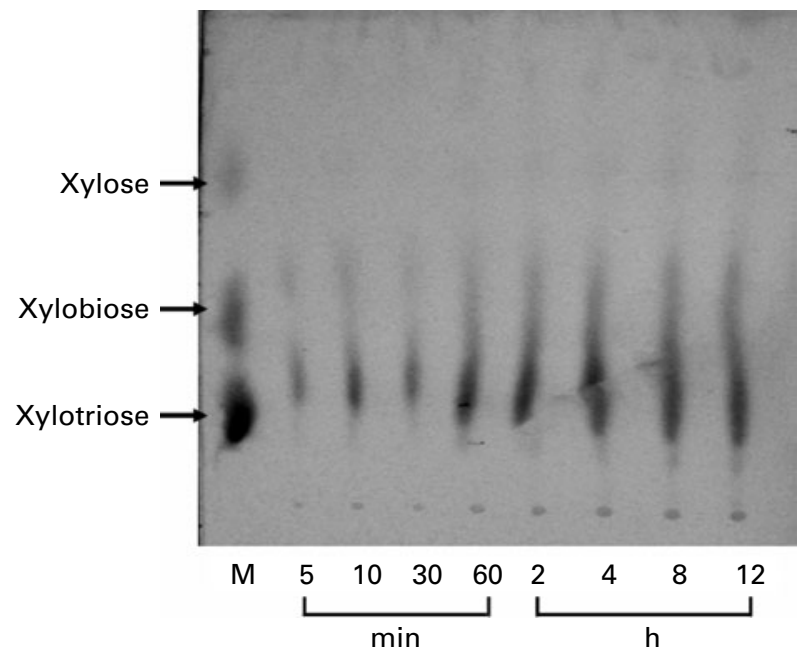

Fig. 4. Analysis of the hydrolysed products by recombinant xylanase 2 . Oalt-spelt xylan $(40 \mathrm{mg})$ was incubated with $100 \mathrm{U}$ of the enzyme in $2 \mathrm{ml}$ $50 \mathrm{~mm}$-citrate phosphate $(\mathrm{pH} 5.0)$ and the reaction was performed at $50^{\circ} \mathrm{C}$ for $12 \mathrm{~h}$ and then the hydrolysates were analysed by TLC. M, protein marker.

(increased $16.9 \% ; P<0.05$ ). But the MD and HD groups (a higher concentration of Xyn2 supplementation) failed to present a positive effect on average body-weight gain $(P>0 \cdot 10)$. There was no effect of enzyme treatment on feed intake in the LD group $(P>0 \cdot 10)$. However, the feed intake for the MD and HD groups decreased by $6.7 \% \quad(P<0.05)$ and $5.1 \%(P=0.07)$, respectively (Fig. 6(A)). The ratio of feed intake:body-weight gain significantly decreased in the LD group $(P<0.05)$. Like with the feed intake, a higher concentration of Xyn2 supplementation did not improve the feed efficiency (Fig. 6(B)).

\section{Effect of xylanase 2 on nutrient digestibility of weaned pigs}

There was a positive effect $(0 \cdot 05<P<0 \cdot 10)$ on the apparent digestibility values of crude protein, ash, $\mathrm{Ca}$ and aciddetergent fibre upon Xyn2 supplementation in the LD group (Table 3 ). However, there was no positive effect of enzyme treatment on energy utilisation $(P>0 \cdot 10)$. Compared with the control group, most of the digestibility values in the MD and HD groups were not improved by enzyme supplementation. On the contrary, there was a negative effect on the digestibility values of $\mathrm{Ca}$ in the $\mathrm{MD}$ and HD groups.

\section{Discussion}

In recent years, several commercial enzymes have been produced to act on carbohydrates not readily digested by single-stomached animals. These are known as NSP and have anti-nutritional properties, depressing animal performance ${ }^{(16)}$. NSP of particular concern include $\beta$-glucans, xylans, pentosans and arabinogalactans. Today, the two extensively used enzymes are xylanase in wheat-based diets and $\beta$-glucanase in barley-based diets. Enzyme supplementation to diets for poultry has usually shown more beneficial effects than supplementation to diets for pigs, particularly if highly viscous diets are used ${ }^{(3)}$. The mechanisms of xylanase action can be attributed to the reduced water-holding capacity and subsequent gut fill, and increased digestibility of the cell wall fraction, and a decrease in gut viscosity, resulting in a greater exposure of the gut contents to absorptive surfaces ${ }^{(17)}$.

Currently, heterologous expression has become one of the main tools for the production of industrial enzymes ${ }^{(18)}$. Many xylanase genes have been successfully expressed in different hosts ${ }^{(6-8)}$. In our laboratory, the xyn2 gene of $T$. reesei, coding Xyn2, was previously expressed in $P$. pastoris. The complete characterisation of the recombinant enzyme (Xyn2) is a key-point condition to evaluate the possibility of its use in industrial applications. As shown in the present study, the recombinant Xyn2 is the predominant protein in the extracellular medium (Fig. 1). The molecular mass $(21 \mathrm{kDa})$ is close to previously purified $T$. reesei $\mathrm{Xyn} 2^{(19)}$. The highest $\beta$-xylanase activity $(560 \mathrm{U} / \mathrm{ml})$ for PX-1 was obtained in a 15 litre fermenter after $78 \mathrm{~h}$ fermentation (Fig. 2). The expression level is higher than that of levels obtained from a recombinant Saccharomyces cerevisiae strain $(90 \mathrm{U} / \mathrm{ml})^{(7)}$ or any Escherichia coli expression system $^{(20,21)}$. The expression level compares well with that of hyperproducing mutant $T$. reesei VTT-D-86271 (324 U/ $\mathrm{ml}$ ) if one takes into account that the $T$. reesei culture supernatant fraction contains the complete battery of enzymes involved in xylan degradation ${ }^{(22)}$. The $\mathrm{pH}$ and temperature optima ( $\left.\mathrm{pH} 6.0 ; 60^{\circ} \mathrm{C}\right)$ of the recombinant Xyn2 compares well with Xyn2 secreted by recombinant $S$. cerevisiae ${ }^{(7)}$. Both of them have a moderate thermostability and inactivated rapidly above $60^{\circ} \mathrm{C}$. The hydrolytic activity of the recombinant Xyn 2 on various substrates was determined in the present study (Table 2). The highest activity (100\%) was observed with the oat-spelt xylan as the substrate followed by the birchwood xylan $(91 \%)$. The $K_{m}$ for oat-spelt xylan and birchwood xylan was 1.1 and $1.8 \mathrm{mg} / \mathrm{ml}$, respectively. The higher affinity towards oat-spelt xylan indicated that the recombinant Xyn2 is more suitable for use in the feed industry other than the paper industry. The products of hydrolysis of oat-spelt xylan were predominantly xylotriose and xylobiose

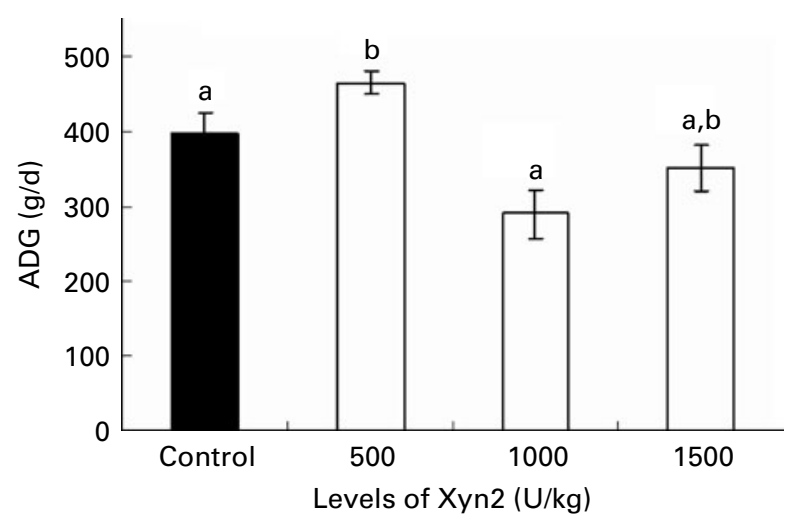

Fig. 5. Effect of recombinant xylanase 2 (Xyn2) supplementation on average daily body-weight gain (ADG) in weaned pigs $(n 6)$. Values are means, with standard errors represented by vertical bars. ${ }^{a, b, c}$ Mean values with unlike letters were significantly different $(P<0.05)$. 

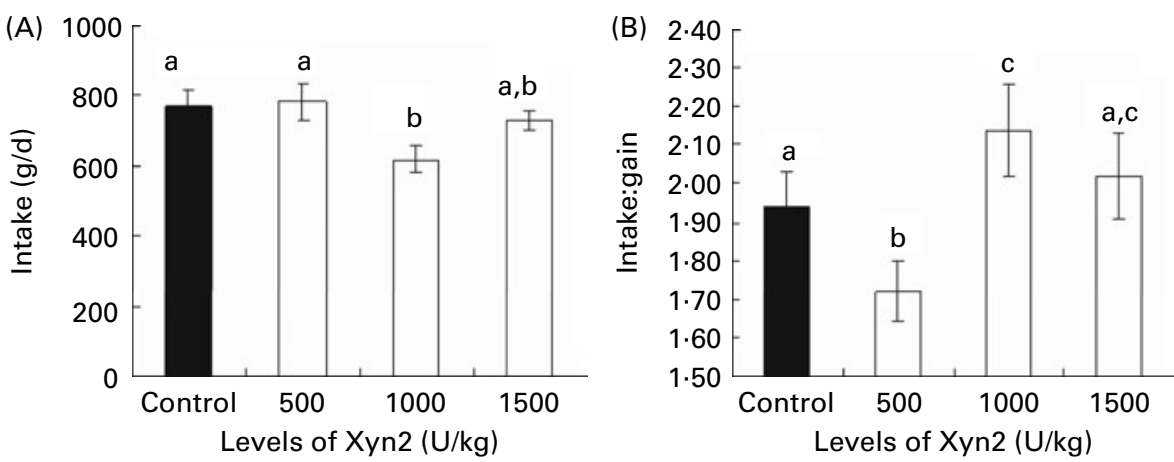

Fig. 6. Effect of recombinant xylanase 2 (Xyn2) supplementation on feed intake $(A)$ and feed efficiency (B) in weaned pigs $(n 6)$. Values are means, with standard errors represented by vertical bars. ${ }^{\mathrm{a}, \mathrm{b}, \mathrm{c}}$ Mean values with unlike letters were significantly different $(P<0.05)$.

and a smaller amount of xylose (Fig. 4), which confirmed the endo-acting nature of the recombinant Xyn2. The xylo-oligosaccharides (i.e. xylobiose) have been found to have a stimulatory effect on the selective growth of intestinal bifidobacteria, which are important for the maintenance of a healthy intestinal microflora ${ }^{(23)}$.

In the present study, the potential benefits of the recombinant enzyme in the nutrition of weaned pigs have been validated. Previous study has shown that pigs receiving enzyme-supplemented diets usually fail to show the same consistent improvements in nutrient digestibilities and growth performance as observed in poultry ${ }^{(24)}$. However, in young pigs, poor nutrient utilisation has been attributed, in part, to the immaturity of the digestive system, including hydrolysis of NSP. Significant improvements in growth performance and nutrient digestibilities were observed when xylanase was supplemented to wheat-based diets ${ }^{(3)}$. In the present study, our statistics results showed a significant linear response to the recombinant xylanase. The supplementation of recombinant Xyn2 (500 U/kg diet) increased the apparent digestibilities of crude protein, ash, $\mathrm{Ca}$ and acid-detergent fibre, which is consistent with an improved performance (average body-weight gain) and feed efficiency (Fig. 5). Yin et al. ${ }^{(25)}$ also reported increases in the digestibilities of some nutrients when xylanase was supplemented to a wheat-based diet in studies with grower pigs. It has to be mentioned that xylanase supplementation may not be effective if sufficient amounts of the target substrate are unavailable. In the present study, the entire diet contained xylans at a level of $5.76 \%$.

Despite the positive effect of enzyme supplementation on performance and nutrient digestibilities in the LD group, there was no improvement of such parameters in the MD and HD groups. This might be explained, in part, by the liquid form of the enzyme. The enzyme prepared through fermentation usually has a bad odour. The bad odour together with a greater enzyme supplementation in the diet may decrease the feed intake. This was supported by the present results, as the feed intake decreased $6.7 \%$ in the MD group and $5.1 \%$ in the HD group, respectively (Fig. 6(A)). Therefore, a proper process step, such as ultrafiltration, dilution and spray drying is indispensable to the fermentative products $^{(26,27)}$.

In conclusion, the results obtained from the present study indicated that the recombinant Xyn2 is more suitable for use in the feed industry. A diet supplemented with the unprocessed enzyme at a lower level improves both the performance and nutrient digestibilities in weaned pigs. However, a proper process is needed to improve its potential benefits in the nutrition of young pigs.

Table 3. Influence of recombinant xylanase 2 (Xyn2) supplementation on nutrient digestibilities of weaned pigs $(n 6)$

(Mean values with their standard errors)

\begin{tabular}{|c|c|c|c|c|c|c|c|c|}
\hline \multirow[t]{2}{*}{ Treatment... } & \multicolumn{2}{|c|}{ Control } & \multicolumn{2}{|c|}{ LD } & \multicolumn{2}{|c|}{ MD } & \multicolumn{2}{|c|}{$\mathrm{HD}$} \\
\hline & Mean & SEM & Mean & SEM & Mean & SEM & Mean & SEM \\
\hline Crude protein & $83 \cdot 7^{\mathrm{a}}$ & $6 \cdot 1$ & $85 \cdot 1^{b}$ & $5 \cdot 8$ & $83 \cdot 7^{\mathrm{a}}$ & $5 \cdot 7$ & $82 \cdot 5^{a}$ & $6 \cdot 4$ \\
\hline Organic matter & $90 \cdot 8$ & 7.4 & 91.4 & 6.9 & $90 \cdot 3$ & $7 \cdot 1$ & $90 \cdot 3$ & $7 \cdot 3$ \\
\hline Crude ash & $73.9^{a}$ & 5.0 & $75 \cdot 7^{\mathrm{b}}$ & $4 \cdot 7$ & $71 \cdot 3^{a}$ & 6.0 & $73 \cdot 4^{\mathrm{a}}$ & 5.9 \\
\hline $\mathrm{Ca}$ & $74 \cdot 6^{\mathrm{a}}$ & $5 \cdot 1$ & $77 \cdot 1^{\mathrm{b}}$ & $6 \cdot 0$ & $69.0^{c}$ & $4 \cdot 8$ & $75 \cdot 3^{\mathrm{a}}$ & $6 \cdot 2$ \\
\hline$P$ & $81 \cdot 6^{\mathrm{a}}$ & $6 \cdot 8$ & $82 \cdot 3^{a}$ & $7 \cdot 1$ & $79 \cdot 8^{\mathrm{b}}$ & $7 \cdot 4$ & $80 \cdot 7^{\mathrm{a}, \mathrm{b}}$ & $7 \cdot 6$ \\
\hline Acid-detergent fibre & $39.5^{\mathrm{a}}$ & $3 \cdot 2$ & $43 \cdot 2^{b}$ & 3.9 & $41 \cdot 6^{\mathrm{a}, \mathrm{b}}$ & $5 \cdot 3$ & $39 \cdot 7^{\mathrm{a}}$ & 4.9 \\
\hline Gross energy & 89.9 & $5 \cdot 3$ & 89.9 & 4.7 & 89.0 & $5 \cdot 1$ & 89.1 & $6 \cdot 2$ \\
\hline
\end{tabular}

Control, without Xyn2 supplementation; LD, Xyn2 added at a concentration of $500 \mathrm{U} / \mathrm{kg}$ diet; MD, Xyn2 added at a concentration of $1000 \mathrm{U} / \mathrm{kg}$ diet; HD, Xyn2 added at a concentration of $1500 \mathrm{U} / \mathrm{kg}$ diet.

a,b,c Mean values within a row with unlike superscript letters were marginally significantly different $(P<0 \cdot 10)$ 


\section{Acknowledgements}

The present study was funded by the Feed Biotechnology Project of Sichuan Province of China with grant no. 2007Z06-050, the Youthfund Project of Sichuan Ministry of Education with grant no. 00924200 and the Program for Changjiang Scholars and Innovative Research Team in University with grant no. IRTO555-5, China Ministry of Education.

J. H., J. Y. and L. W. participated in the experimental design, carried out the molecular genetic and biochemical experiments, participated in data interpretation and helped draft the manuscript. B. Y. conceived of the study. D. C. directly supervised the project, participated in its experimental design and data interpretation and was responsible for writing the manuscript.

The authors state that there are no conflicts of interest in this field.

\section{References}

1. Bailey P (1985) Microbial xylanolytic systems. Trends Biotechnol 3, 286-290.

2. Esteve-Garcia E, Brufau J, Perez-Vendrell A, et al. (1997) Bioefficacy of enzyme preparation containing $\beta$-glucanase and xylanase activities in broiler diets based on barley or wheat, in combination with flavomycin. Poult Sci 76, 1728-1737.

3. Diebold G, Mosenthin R, Piepho HP, et al. (2004) Effect of supplementation of xylanase and phospholipase to a wheatbased diet for weanling pigs on nutrient digestibility and concentrations of microbial metabolites in ileal digesta and feces. J Anim Sci 82, 2647-2656.

4. Wong KKY \& Saddler JN (1992) Trichoderma xylanases, their properties and application. Crit Rev Biotechnol 12, 413-435.

5. Törrönen A, Harkki A \& Rouvinen J (1994) Three-dimensional structure of endo-1, 4- $\beta$-xylanase II from Trichoderma reesei: two conformatinal states in the active site. EMBO $J \mathbf{1 3}$, 2493-2501.

6. Saarelainen R, Paloheimo M, Fagerström R, et al. (1993) Cloning sequencing and enhanced expression of the Trichoderma reesei endoxylanase II gene. Mol Gen Genetics 241, 497-503.

7. La Grange DC, Pretorius IS \& Van Zyl WH (1996) Expression of a Trichoderma reesei $\beta$-xylanase gene (XYN2) in Saccharomyces cerevisiae. Appl Environ Microbiol 62, 1036-1044.

8. Jiang ZQ, Deng W, Zhu YP, et al. (2004) The recombinant xylanase B of Thermotoga maritima is highly xylan specific and produces exclusively xylobiose from xylans, a unique character for industrial applications. $J$ Mol Catalysis B: Enzymatic 27, 207-213.

9. Laemmli UK (1970) Cleavage of structural proteins during the assembly of the head of bacteriophage T4. Nature (London) 227, 680-685.
10. Bradford MM (1976) A rapid sensitive method for the quantitation of microgram quantities of protein utilizing the principle of protein-dye binding. Anal Biochem 72, 248-254.

11. Bailey MJ, Biely P \& Poutanen K (1992) Interlaboratory testing of methods for assay of xylanase activity. J Biotechnol $\mathbf{2 3}$, 257-270.

12. Miller GL, Blum R, Glennon WE, et al. (1960) Measurement of carboxymethyl-cellulase activity. Anal Biochem 2, 127-132.

13. National Research Council (1998) Nutrient Requirements for Swine, 10th ed. Washington, DC: National Academy Press.

14. AOAC (1990) Official Methods of Analysis, 15th ed. Washington, DC: Association of Official Analytical Chemists.

15. Van Soest PJ, Robertson JB \& Lewis BA (1991) Methods for dietary fiber, neutral detergent fiber, and nonstarch polysaccharides in relation to animal nutrition. $J$ Dairy Sci 74, 3583-3597.

16. Jaroni D, Scheideler SE, Beck M, et al. (1999) The effect of dietary wheat middlings and enzyme supplementation on late egg production efficiency, egg yields, and egg composition in two strains of leghorn hens. Poult Sci 78, 841-847.

17. Cadogan DJ, Choct M, Campbell RG, et al. (1999) Effects of new season wheat on the growth performance of young male pigs. In Manipulating Pig Production, p. 40 [PD Granwell, editor]. VII Werribee, Vic: Australian Pig Science Association.

18. Kirk O, Borchert TV \& Fuglsang CC (2002) Industrial enzyme application. Curr Opin Biotechnol 13, 345-351.

19. Törrönen A, Mach RL, Messner R, et al. (1992) The two major xylanases from Trichoderma reesei: characterization of both enzymes and genes. Biotechnology 10, 1461-1465.

20. Junli H, Guixue W \& Li X (2006) Cloning, sequencing and expression of the xylanase gene from a Bacillus subtilis strain B10 in Escherichia coli. Bioresour Technol 97, 802-808.

21. Chenyan Z, Jiangyu B, Shanshan D, et al. (2008) Cloning of a xylanase gene from Aspergillus usamii and its expression in Escherichia coli. Bioresour Technol 99, 831-838.

22. Bailey MJ, Buchert J \& Viikari L (1993) Effect of pH on production of xylanase by Trichoderma reesei on xylan- and cellulose-based media. Appl Microbiol Biotechnol 40, 224-229.

23. Jeong KJ, Park IY, Kim MS, et al. (1998) High-level expression of an endoxylanase gene from Bacillus sp. in Bacillus subtilis DB104 for the production of xylobiose from xylan. Appl Microbiol Biotechnol 50, 113-118.

24. Partridge GG \& Bedford MR (2000) The role and efficacy of carbohydrase enzymes in pig nutrition. In Enzymes in Farm Animal Nutrition, pp. 161-198 [GG Partridge and MR Bedford, editors]. Wallingford, UK: CABI Publishing.

25. Yin YL, McEvoy DG, Schulze H, et al. (2000) Apparent digestibility (ileal and overall) of nutrients and endogenous nitrogen losses in growing pigs fed wheat or its by-products without or with xylanase supplementation. Livest Prod Sci 62, 119-132.

26. Susanto H, Arafat H, Janssen EML, et al. (2008) Ultrafiltration of polysaccharide-protein mixtures: elucidation of fouling mechanisms and fouling control by membrane surface modification. Sep Purif Technol 63, 558-565.

27. Langrish TAG \& Fletcher DF (2001) Spray drying of food ingredients and applications of CFD in spray drying. Chem Eng Process 40, 345-354. 